Original Research Paper

\title{
Lumbricus rubellus Protein Fraction DLBS1033N Increases Nerve Growth Factor Expression via Tyrosine Kinase Activation
}

\author{
Agung Heru Karsono, Raymond Rubianto Tjandrawinata and Maggy Thenawidjaja Suhartono \\ Faculty of Biotechnology, Atma Jaya Catholic University of Indonesia, \\ Jalan Jenderal Sudirman 51, Jakarta 12930, Indonesia
}

Article history

Received: 26-07-2016

Revised: $14-04-2017$

Accepted: 03-02-2018

Corresponding Author: Raymond R. Tjandrawinata Faculty of Biotechnology, Atma Jaya Catholic University of Indonesia, Jalan Jenderal Sudirman 51, Jakarta 12930, Indonesia

Email: raymond@dexa-medica.com

\section{Introduction}

Nervous system can be divided into central nervous and peripheral nervous system. Both systems have different anatomical structure and regeneration abilities. Nerve could be injured due to mechanical, thermal, chemical, or ischemic factors (Zhang et al., 2005). Nerve regeneration is needed when the nerve is degenerated or injured (Bunge, 1993). However, nerve regeneration is more possible in the peripheral nervous system due to the anatomical structure and the necessary biochemical reaction (Chen et al., 2007). Schwann cells are a part of the peripheral nervous system involved in nerve regeneration process. When the peripheral nerve injury occurred, Schwann cells with macrophages were assisted in the removal of axonal and myelin debris (Bunge, 1994). Axon regeneration and remyelination are needed for nerve regeneration process. The Schwann cells will differentiate and proliferate in order to form Bungner bands that will allow axon regeneration and ensue remyelination after injury (Bunge, 1993; 1994; Ide, 1996).
Another important factor in peripheral nerve regeneration process is neurotrophins which are the regulators of neural survival, development, function and plasticity (Bunge, 1993; 1994; Ide, 1996; Huang and Reichardt, 2001). Some neurotrophins such as Nerve Growth Factor (NGF) and Brain Derived Neurotrophic Factor (BDNF) are produced by Schwann cells. Neurotrophins are released around regenerating axon (Ide, 1996). At least four neurotrophins have been well characterized in mammals: NGF, BDNF, neurotrophin-3 (NT-3) and neurotropin-4 (NT-4). The neurotrophins bind two types of receptor, tyrosine kinase receptors and lowaffinity NGF receptor p75 (Hallbook, 1999). NGF binds specifically to TrkA; BDNF and NT-4 bind specifically to TrkB; and NT-3 binds to TrkC (Huang and Reichardt, 2001; Hallbook, 1999; Lewin and Barde, 1996).

Therapeutic proteins have been increased in numbers and uses since the introduction of recombinant insulin therapy. Therapeutic proteins can be obtained from their native sources or from recombinant technology (Leader et al., 2008). Earthworm is one example of the 
source of therapeutic protein extracted from their native source. Lumbrokinase is a common therapeutic protein obtained from earthworm that possess thrombolytic effect (Mihara et al., 1989; 1991; Cho et al., 2004; Verma and Pulicherla, 2011). However, reports showed that earthworm extract also possessed other activity, in addition toits thrombolytic effect. Study by Chang et al. (2011a; 2009) showed that earthworm extract exhibited good activity on peripheral nerve regeneration.

In this study, earthworm Lumbricus rubellus protein fraction DLBS1033N was used as therapeutic protein candidate for peripheral nerve regeneration treatments. The experiments were designed to observe DLBS1033N activity on Schwann cell growth and survival in free serum and free serum-with minimum $\mathrm{O}_{2}$ conditions. The conditions were prepared for mimicking hypoxia-ischemic state. In this study, the experiments were also designed to investigate DLBS1033N activity in inducing neurotrophins.

\section{Materials and Methods}

\section{DLBS1033N Preparations}

Protein fraction DLBS1033N was made using Lumbricus rubellus protein fraction DLBS1033 provided by Dexa Laboratories of Biomolecular Sciences (DLBS) (Trisina et al., 2011). DLBS1033 (1 mg mL $\left.{ }^{-1}\right)$ was hydrolyzed with heat $\left(100^{\circ} \mathrm{C}\right)$ in a water bath for $30 \mathrm{~min}$. The liquid $\left( \pm 1 \mathrm{mg} \mathrm{mL}^{-1}\right)$ was then sterilized with 0.22 $\mu \mathrm{m}$ filter before the use for cells treatments.

\section{Materials}

TrkA inhibitor, GW441756 was purchased from Sigma (MO, USA). Oxygen absorber Anaerocult ${ }^{\circledR}$ was purchased from Merck (Darmstadt, Germany). Collagen for neurite outgrowth assay was purchased from Sigma (MO, USA).

\section{Cell Culture}

Schwann cell line Rattus norvegicus RSC96 (ATCC ${ }^{\circledR}$ CRL2765 ${ }^{\mathrm{TM}}$ ) and adrenal gland Rattus

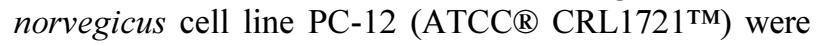
purchased from American Type Culture Collection (Rockville, MD, USA). The RSC96 cells were cultured in DMEM media with $10 \%$ Fetal Bovine Serum and 1\% Penicillin/Streptomycin (Gibco, Grand Island, USA). The PC-12 cells were cultured in RPMI 1640 media with $10 \%$ Fetal Bovine Serum and 1\% Penicillin/Streptomycin (Gibco, Grand Island, USA). The RSC96 and PC-12 cells were cultured in $37^{\circ} \mathrm{C}, 5 \% \mathrm{CO}_{2}$ conditions.

\section{Cell Proliferation Assay}

To do the cell proliferation assay in free serum condition, RSC96 cells were cultured in 96-well plate at $1 \times 10^{3}$ cells/well. Meanwhile, to do cell proliferation in hypoxia-ischemic condition, RSC96 cell were cultured in $6 \mathrm{~cm}$ petri dish at $2 \times 10^{5}$ cells per petri dish. RSC96 cells were treated with $25,50,75$ or $100 \mu \mathrm{g} \mathrm{mL}$ DLBS1033N for 24,48 or $72 \mathrm{~h}$. For hypoxia condition, RSC96 cells were incubated with free serum media for 4 $\mathrm{h}$ before cultured in sealed beaker glass containing oxygen absorber Anaerocult $\AA$. RSC96 cells were incubated for $24 \mathrm{~h}$ with $50 \mu \mathrm{g} \mathrm{mL} \mathrm{mL}^{-1}$ DLBS1033N. Cell viability was observed using CellTiter 96® AQueous Non-Radioactive Cell Proliferation Assay Reagents (Promega, Fitchburg, WI, USA).

\section{FACS Cell Analysis}

RSC96 cells were cultured in 6 -well plate at $1 \times 10^{5}$ cells/well. In the following day, the culture media was exchanged with free serum media and incubated for $4 \mathrm{~h}$ prior to any treatment. RSC96 cells were treated with 50 $\mu \mathrm{g} \mathrm{mL} \mathrm{mLBS}^{-1}$ DL33N for 24,36 or $72 \mathrm{~h}$, then harvested (either live or death cells) into pellets. The cell pellets were washed with PBS and fixed with $300 \mu \mathrm{L}$ PBS and $700 \mu \mathrm{L}$ ethanol. The sample was incubated at $4{ }^{\circ} \mathrm{C}$ for at least $24 \mathrm{~h}$ before running in FACS machine. After incubation, the fixed cells were centrifuged to obtain the cell pellets. Propidium iodide was added to the cell pellets for $1 \mathrm{ml}$ and further incubated for $30 \mathrm{~min}$ in dark conditions. The sample was run in FACS machine (BD, San Jose, CA, USA) and analyzed with Cell Quest program (BD, San Jose, CA, USA).

\section{RNA Preparation and Real-Time Assay}

RSC96 cell were cultured on 6 well plate at $1 \times 10^{5}$ cells/well. In the following day, free serum media was administrated for $4 \mathrm{~h}$ prior to the treatments. RSC96 cells were treated with $50 \mu \mathrm{g} \mathrm{mL} \mathrm{m}^{-1}$ DLBS1033N for $48 \mathrm{~h}$. Total RNA was isolated using Trizol reagent (Invitrogen, CA, USA). The RNA concentration was quantified using NanoDrop 2000c spectrophotometer (Thermo Scientific, Waltham, MA, USA). Reverse transcription of total RNA $(1 \mu \mathrm{g})$ was done using GoScript reagent from Promega (Fitchburg, WI, USA). Expression was carried out using gene-specific primers NGF F: 5'CCCGAATCCTGTAGAGAGTGG-3', R: 5'GACAAAGGTGTGAGTCGTGG-3'; FGF F: 5'-CGT CAAACTACAGCTCCAAGCAGA, R: 5'GGATTCGAGTTTATACTGCCCAGT-3'; GDNF F: 5'GCC GCCGAAGACTCCCTC-3', R: 5'GTGCCGCCGCTTGTTTATCTGG-3'; BDNF F: 5'-GGC CCAACGAAGAAAACCAT-3'; PI3K F: 5'ACACTTGGGGGACATCCTGA-3', R: 5'-TCT CCCСTCTCCCCAGTAGT-3'; Akt F: 5'GTGTGTGGACAGTGAACGGA-3', R: 5'-GAT GATCCATGCGGGGCTTC-3'; BAD F: 5'TGGCTATGTTCCCTCTCCGT-3', R: 5'-CAC GTTTCTTGACCTGGGGC-3'; BCL-2 F: 5'ACTCTTCAGGGATGGGGTGA-3', R: 5'-GCA TGCTGGGGCCATATAGT-3', BCL-xL F: 5'- 


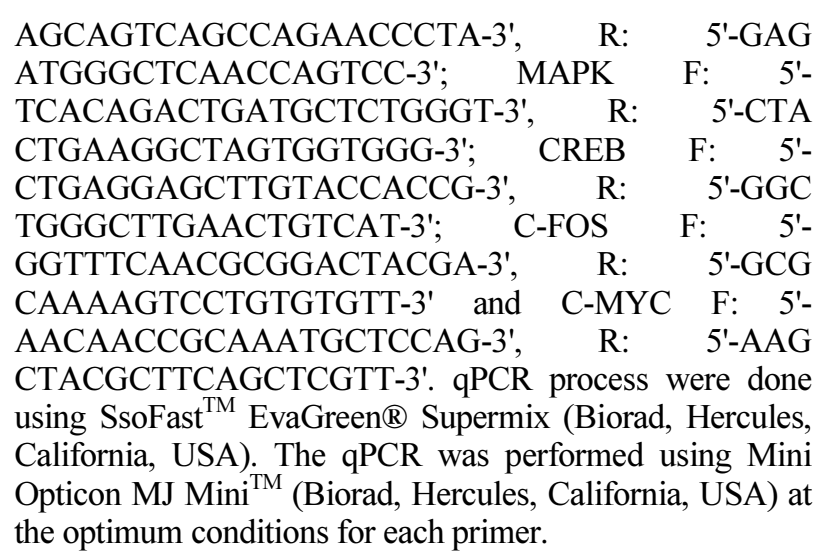

NGF ELISA Assay

RSC96 cells were cultured in $6 \mathrm{~cm}$ petri dish at $2 \times 10^{5}$ cells/well. In the next day, the free serum media was given to the cells for $4 \mathrm{~h}$ prior to treatments. RSC96 cells were treated with $50 \mu \mathrm{g} \mathrm{mL} \mathrm{mL}^{-1}$ DLBS1033N for $48 \mathrm{~h}$. Total protein from media was concentrated using Amicon ${ }^{\circledR} \quad$ Ultra-15 (MerckMillipore, Darmstadt, Germany) from $2 \mathrm{~mL}$ to $200 \mu \mathrm{L}$. NGF in media was investigated using ChemiKine ${ }^{\mathrm{TM}}$ NGF ELISA kit (Merck, Darmstadt, Germany) according to the manufacturer's protocol.

\section{Neurite Growth Induction}

Neurite growth assay was adapted from Smit et al. (2003) and Yang et al. (2014) with some modifications. Twelve-well plate were prepared for neurite growth induction. The plate was coated with extracellular matrix reagents containing collagen/PBS, $0.3 \mathrm{mg} \mathrm{mL}^{-1}$, for $4 \mathrm{~h}$. PC-12 cells were plated on 12 -well plate for $5 \times 10^{4}$ cells/well. The PC-12 cells were treated with $50 \mu \mathrm{g} \mathrm{mL}^{-1}$ DLBS1033N for $72 \mathrm{~h}$.

\section{Statistical Analysis}

Data are presented as the mean \pm Standard Error (S.E.). Significant differences between experimental values were determined using student t-test with $\mathrm{p}<0.05$ considered as significance.

\section{Results}

\section{DLBS1033N Induces Growth and Survival in Free Serum and Free Serum-Minimum $\mathrm{O}_{2}$ Conditions}

In this study, RSC96 (ATCC ${ }^{\circ}$ CRL2765'M) Schwann cell was used. The cell was prepared in two conditions, which consisted of free serum media for up to $72 \mathrm{~h}$, and free serum media and minimum $\mathrm{O}_{2}$ condition for $24 \mathrm{~h}$.

For free serum condition, the DLBS1033N was administrated to the cell with concentrations of 25,50 , 75 and $100 \mu \mathrm{g} \mathrm{mL}^{-1}$. Cell growth was observed after 24 , 48 and $72 \mathrm{~h}$ incubation. The result showed that sample treated with DLBS1033N exhibited more cells populations detected compared to the control (Fig. 1). At $24 \mathrm{~h}$ after treatments, the cells populations were almost identical in number between the positive control (DMEM (+) 10\% FBS), control (DMEM (-) serum only) and sample treated with DLBS1033N. After $48 \mathrm{~h}$ of treatments, the control sample exhibited fewer cells populations compared to the positive control. Cells treated with DLBS1033N were proliferated almost identical to the positive control. The higher cells populations were found on sample treated with $50 \mu \mathrm{g}$ $\mathrm{mL}^{-1}$ DLBS1033N compared to the control sample. After $72 \mathrm{~h}$, the positive control sample showed higher cells population compared to the control and DLBS1033N-treated sample. However, cells populations were higher in DLBS1033N samples compared to the control. Other protein used as a negative control was Bovine Serum Albumin (BSA). The experiments were done for $48 \mathrm{~h}$ with concentrations of DLBS1033N and BSA 25 and $50 \mu \mathrm{g} \mathrm{mL}^{-1}$. The results showed that only DLBS1033N-treated samples have more cells populations compared to the control sample (Fig. 2).

Following FACS analysis result, it was found that $\mathrm{S}$ phase in sample treated with $50 \mu \mathrm{g} \mathrm{mL}^{-1}$ DLBS1033N on 24, 36 and $48 \mathrm{~h}$ were higher than that of the control sample (Fig. 3). After $24 \mathrm{~h}$, the $\mathrm{S}$ phase of control sample and treated sample were $6.8 \% 14.0 \%$, respectively. Moreover, after $36 \mathrm{~h}$, the $\mathrm{S}$ phase of control was $7.4 \%$ and the treated sample was $10.1 \%$. At $48 \mathrm{~h}$, S phase of control was $7.1 \%$ and the treated sample was $8.2 \%$.

The study was continued with growth and survival assay with free serum and minimum $\mathrm{O}_{2}$ conditions for hypoxia-ischemic mimicking condition. The RSC96 cells were treated with $50 \mu \mathrm{g} \mathrm{mL}{ }^{-1}$ DLBS1033N and prepared for the minimum $\mathrm{O}_{2}$ conditions. The plate was sealed with parafilm and inserted into beaker glass containing Anaerocult ${ }^{\circledR}$ then sealed with aluminum foil and parafilm. RSC96 cells were incubated for $24 \mathrm{~h}$. The study shows that RSC96 cells treated with $50 \mu \mathrm{g} \mathrm{mL}$ DLBS1033N were proliferated and survived (Fig. 4).

The results showedthat control sample (minimum $\mathrm{O}_{2}$ ) in hypoxia-ischemic conditions has fewer cells populations compared to the control sample in normal conditions. Meanwhile, cells populations treated with 50 $\mu \mathrm{g} \mathrm{mL} \mathrm{mL}^{-1}$ DLBS1033N in hypoxia-ischemic condition was survived and proliferated. The cells populations were higher than that of control in normal conditions.

\section{DLBS1033N Induces NGF Expressions}

In order to determine the mechanisms of action of the growth and survival activity, gene expression of several neurotrophins and growth factors were investigated using real-time PCR method. The neurotrophins and growth factors studied were NGF, FGF, BDNF and GDNF. The cells were treated with $50 \mu \mathrm{g} \mathrm{mL}$ DLBS1033N for $48 \mathrm{~h}$. The investigation result is shown in Table 1. 


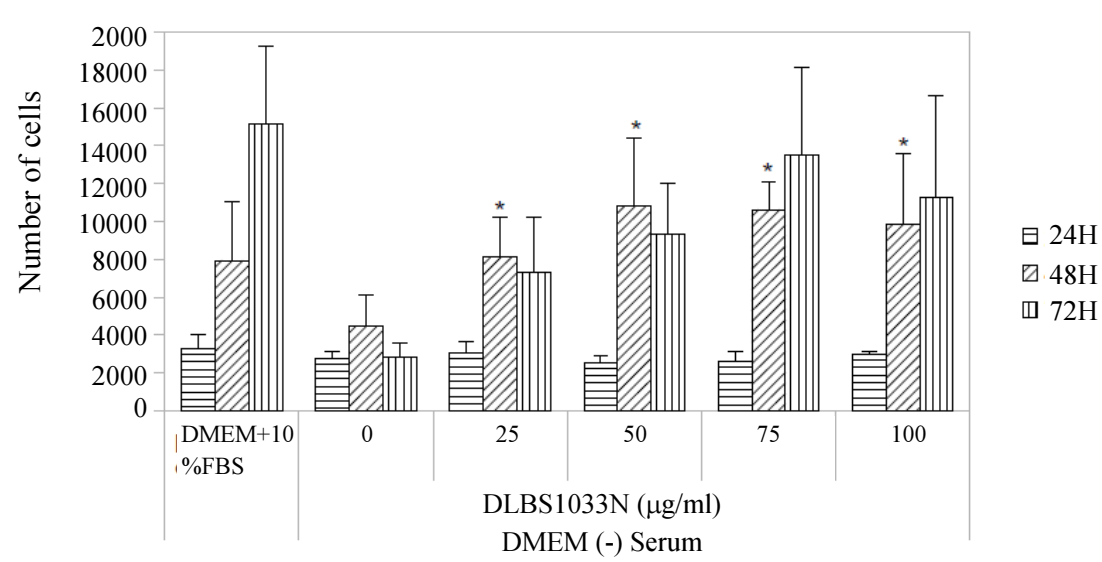

Fig. 1: Cell growth and survival in free serum conditions, RSC96 cells were treated with various concentration of DLBS1033N for 24,48 and $72 \mathrm{~h}$. Values are expressed as means \pm S.E. of eight independent experiments $\left({ }^{*} \mathrm{p}<0.05\right.$, compared with $0 \mu \mathrm{g} \mathrm{mL}{ }^{-1}$ DLBS1033N)

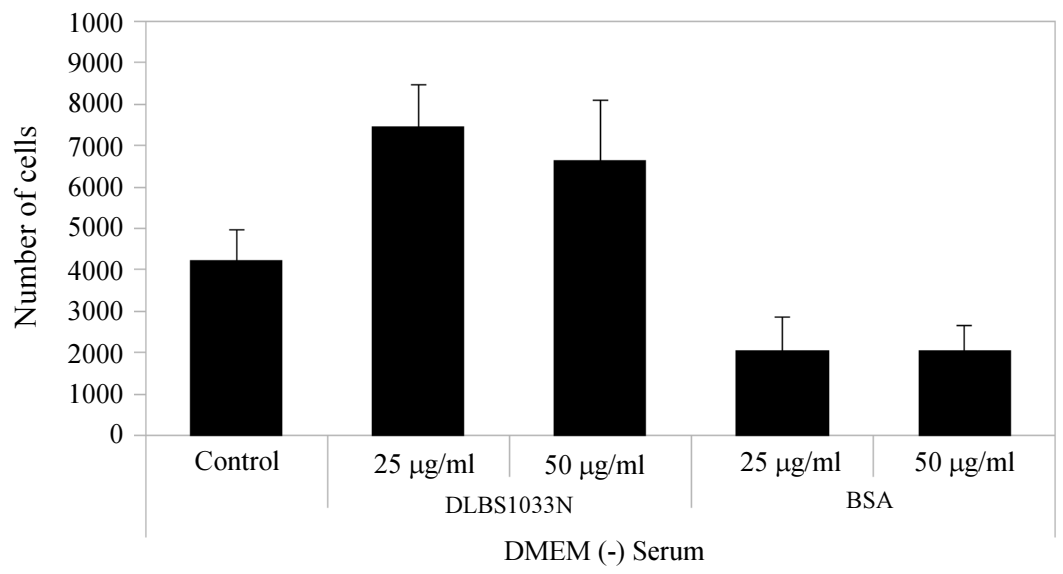

Fig. 2: Other protein (BSA) did not induce growth and survival of RSC96 cells, RSC96 cells were treated with DLBS1033N or BSA 25 and $50 \mu \mathrm{g} \mathrm{mL}^{-1}$ in free serum media. Some samples were also treated with GW441756 $20 \mu \mathrm{g} \mathrm{mL}^{-1}$. Values are expressed as means \pm standard deviation of eight independent experiments $\left({ }^{*} p<0.05\right.$, compared with control)

Table 1: Fold change of several growth factor gene expressions

\begin{tabular}{llll}
\hline & Fold change $(48 \mathrm{H})$ Sample & & \\
Gene & Control & DLBS1033N $\left(50 \mu \mathrm{g} \mathrm{m}^{-1}\right)$ & Std. Deviation \\
\hline NGF & 1 & 1.56 & 0.51 \\
FGF & 1 & 0.53 & 0.08 \\
BDNF & 1 & 0.37 & 0.02 \\
GDNF & 1 & 0.52 & 0.16 \\
\hline
\end{tabular}

The results showed that only NGF gene was upregulated by $50 \mu \mathrm{g} \mathrm{mL} \mathrm{mL}^{-1}$ DLBS1033N at $48 \mathrm{~h}$ incubation. The other neurotrophins and growth factor tend to be down-regulated. It was found that $50 \mu \mathrm{g} \mathrm{mL}^{-1}$ DLBS1033N could up-regulated NGF gene expressions by almost $50 \%$ more than the control. To confirm the action of DLBS1033N in inducing NGF, further study which observed NGF expression at protein level was conducted. The NGF protein was secreted by the cells. Therefore, to investigate NGF protein expressions, the protein in cell media was analyzed with NGF ELISA kit. NGF protein in the cell media from the DLBS1033Ntreated sample was detected (Fig. 5). The NGF-ELISA study revealed that NGF protein in cell media was increased in a time-dependent manner. The NGF

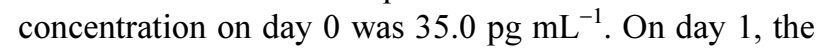
NGF protein concentration was increased up to $35.5 \%$ (compared to day 0 ) to $47.4 \mathrm{pg} \mathrm{mL}^{-1}$. On day 2, the NGF protein was detected and increased up to $45.9 \%$ (compared to day 0) to $51.1 \mathrm{pg} \mathrm{mL}^{-1}$. 
(A)

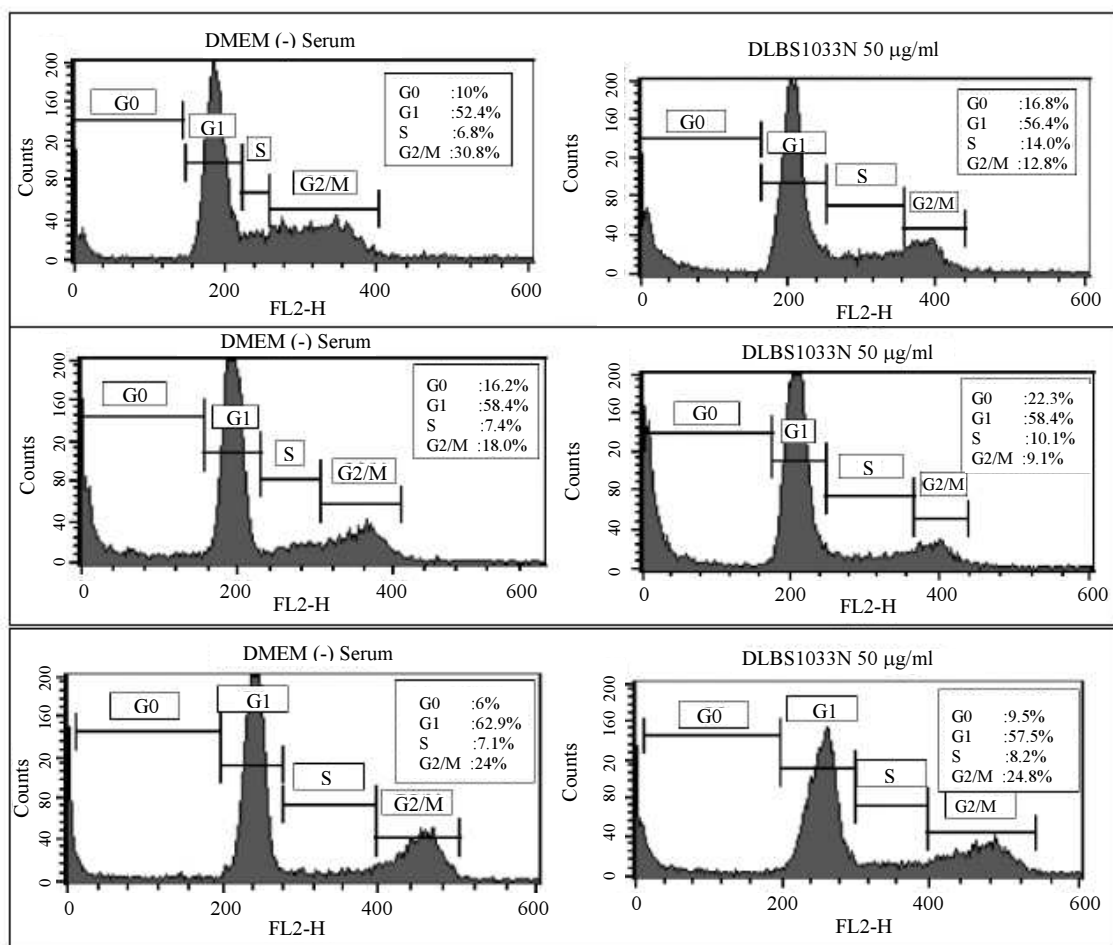

Fig. 3: Cell cycle analysis in RSC96 cells after treated with DLBS1033N, Cell cycle analysis was performed in RSC96 cells after treated with DLBS1033N $50 \mu \mathrm{g} \mathrm{mL}{ }^{-1}$. (A) Peak distribution of each phases G0, G1, S and G2/M after $24 \mathrm{~h}$ treatments. (B) Peak distribution of each phases G0, G1, S and G2/M after 36 hours treatments. (C) Peak distribution of each phases G0, G1, $\mathrm{S}$ and $\mathrm{G} 2 / \mathrm{M}$ after $72 \mathrm{~h}$ treatments

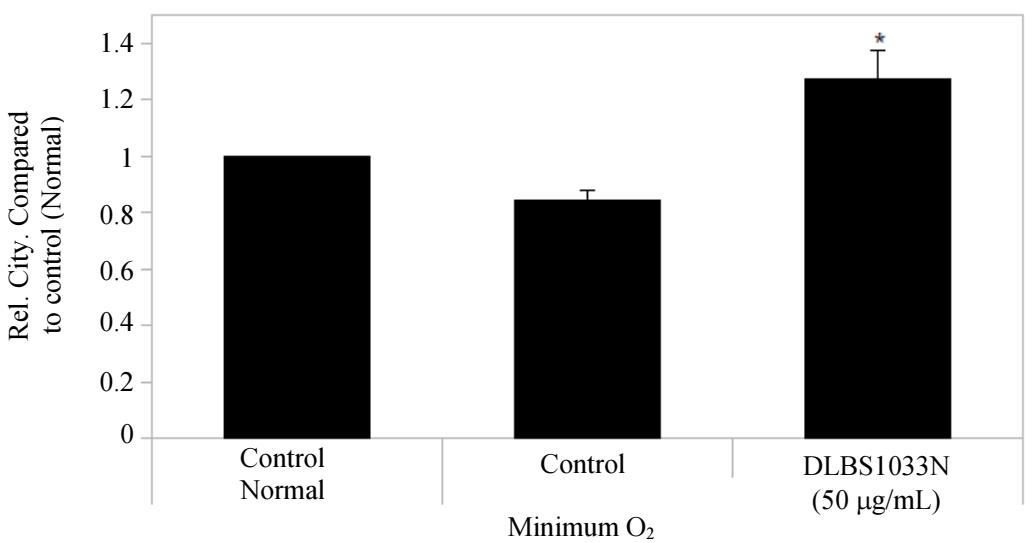

Fig. 4: Cell growth and survival assay in free serum-minimum $\mathrm{O}_{2}$ conditions, Cell survival at minimum $\mathrm{O}_{2}$ condition assay was conducted on RSC96 cell treated with $50 \mu \mathrm{g} \mathrm{mL} \mathrm{m}^{-1}$ DLBS1033N for $24 \mathrm{~h}$. Values are expressed as means $\pm \mathrm{S}$. E. of two independent experiments $\left({ }^{*} \mathrm{p}<0.05\right.$, compared with control-normal)

In order to confirm the action of DLBS1033N on growth and survival through NGF, receptor inhibition study was conducted. The RSC96 cell was treated with $50 \mu \mathrm{g} \mathrm{mL}{ }^{-1}$ DLBS1033N. Inhibitor GW441756 was introduced into some of the DLBS1033N-treated cells with concentrations of $2.5,5,10$ and $20 \mu \mathrm{g} \mathrm{mL}$. Sample treated with GW441756 and DLBS1033N exhibited less cell population compared to DLBS1033N treatment only (Fig. 6). The result showed that
DLBS1033N treatment $\left(50 \mu \mathrm{g} \mathrm{mL} L^{-1}\right)$ resulted in higher cells populations compared to the control. However, when GW441756 was introduced, the cell growth was inhibited. The inhibition appeared as a dose-dependent manner. The higher GW441756 introduced to the DLBS1033N treated cell, the less cell growth effect was detected. The cell growth was inhibited up to $43.9 \%$ by $20 \mu \mathrm{g} \mathrm{mL} \mathrm{m}^{-1} \mathrm{GW} 441756$ (compared to DLBS1033N treatment only). 


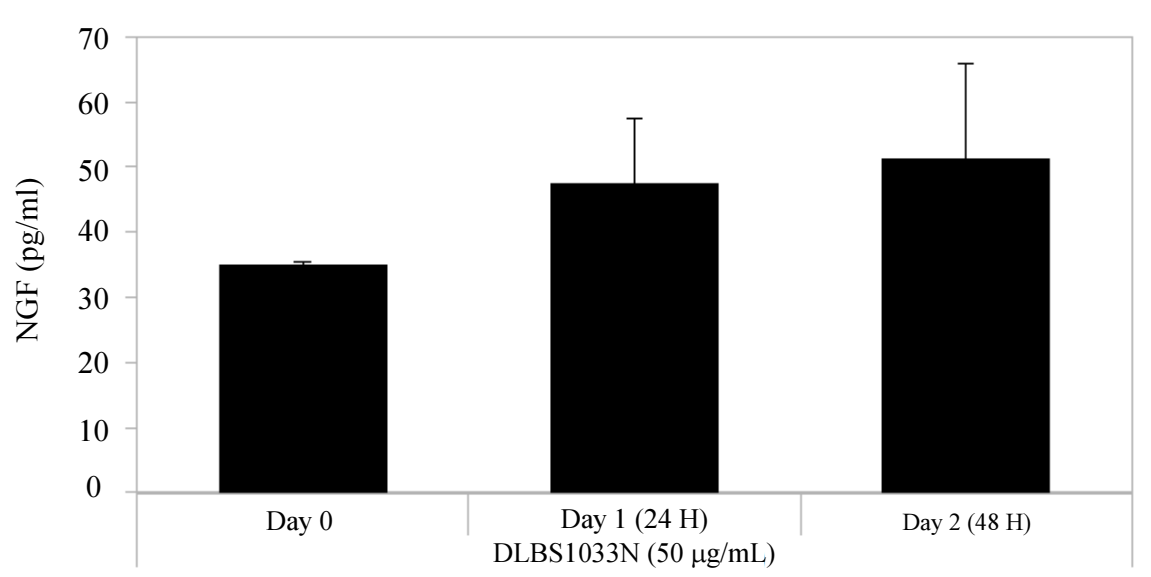

Fig. 5: NGF protein in cells media after treated with DLBS1033N, DLBS1033N induced NGF protein secretion in a time-dependent manner. RSC96 cell was treated with $50 \mu \mathrm{g} \mathrm{mL} \mathrm{mL}^{-1}$ DLBS1033N up to $48 \mathrm{~h}$. The protein sample was isolated using RIPA buffer. NGF protein was detected using ELISA kit

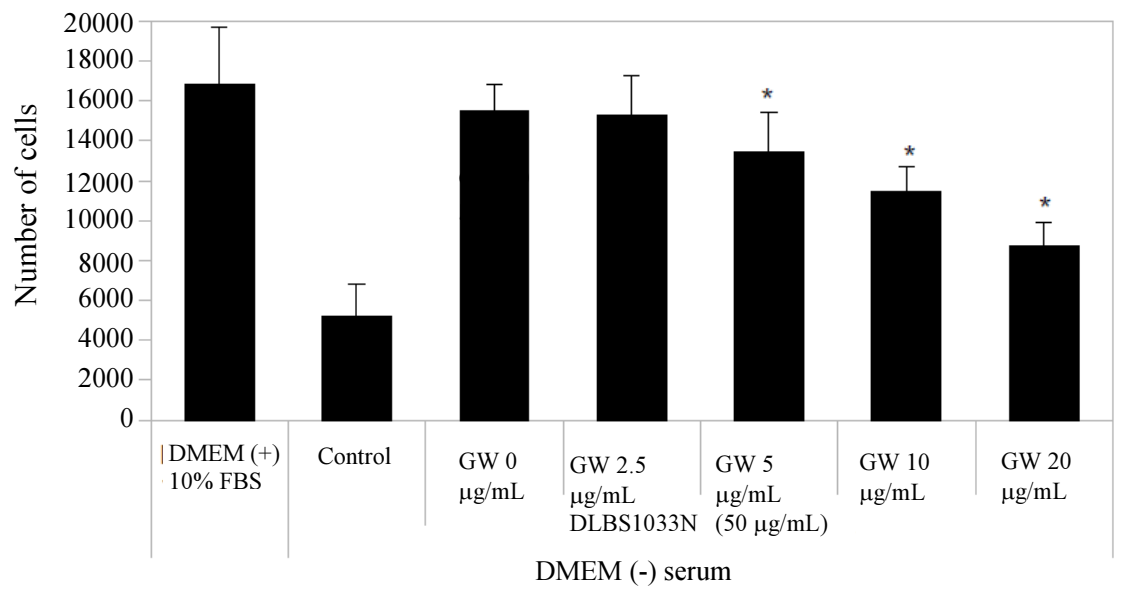

Fig. 6: GW441756 inhibit RSC96 cells growth, GW441756 inhibit cell growth by DLBS1033N. RSC96 cells were treated with/without various concentration of GW441756 ranging from 0 to $20 \mu \mathrm{g} \mathrm{mL} \mathrm{L}^{-1}$ for $48 \mathrm{~h}$. Values are expressed as means \pm S.E. of eight independent experiments $\left(* \mathrm{p}<0.05\right.$, compared with GW441756 $0 \mu \mathrm{g} \mathrm{mL}^{-1}$ )

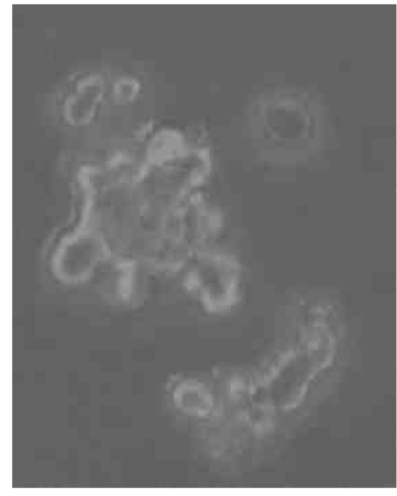

(A)

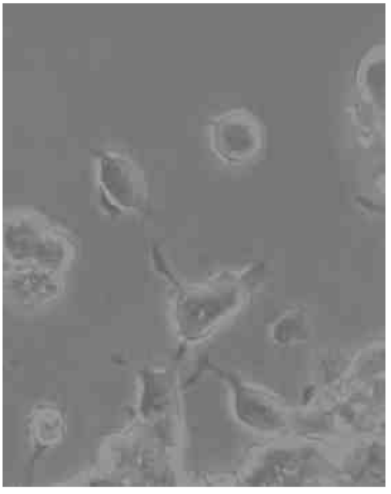

(B)

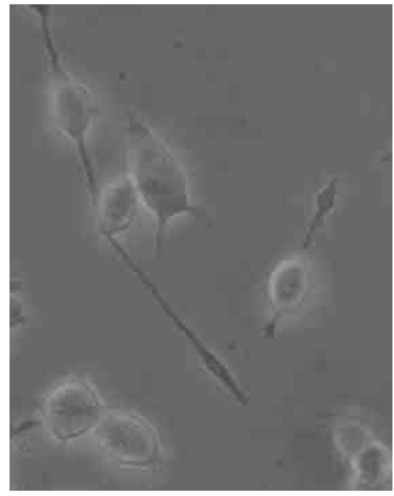

(C)

Fig. 7: DLBS1033N induces neurite outgrowth on PC12, The PC12 cell line was plated on 12-well plate coated with collagen at least $6 \mathrm{~h}$. The PC12 cell line was treated for $72 \mathrm{~h}$. (A) PC12 cell without any treatments. (B) PC12 cell with $0.1 \mathrm{ng} \mathrm{mL}$ NGF. (C) PC12 cell with $50 \mu \mathrm{g} \mathrm{mL}{ }^{-1}$ DLBS1033N 
Table 2: Fold change of genes involved in both PI3K and MAPK pathways

\begin{tabular}{|c|c|c|c|}
\hline \multirow[b]{2}{*}{ PI3K gene } & \multicolumn{3}{|c|}{ Fold change (48H) Sample } \\
\hline & Control & DLBS1033N $\left(50 \mu \mathrm{g} \mathrm{mL}^{-1}\right)$ & Std. Deviation \\
\hline PI3K & 1 & 2.43 & 0.93 \\
\hline Akt & 1 & 1.5 & 0.22 \\
\hline BAD & 1 & 0.51 & 0.24 \\
\hline BCL-2 & 1 & 2.12 & 0.93 \\
\hline BCL-Xl & 1 & 1.34 & 0.18 \\
\hline \multicolumn{4}{|l|}{ MAPK gene } \\
\hline MAPK & 1 & 0.53 & 0.09 \\
\hline CREB & 1 & 0.75 & 0.60 \\
\hline C-FOS & 1 & 0.18 & 0.07 \\
\hline C-MYC & 1 & 0.54 & 0.08 \\
\hline
\end{tabular}

\section{DLBS1033N Induces Neurite Outgrowth}

Neurotrophin NGF was found to induce neurite outgrowth in nerve cell models PC-12 (ATCC® CRL1721 ${ }^{\mathrm{TM}}$ ) cell line (Smit et al., 2003; Greene et al., 1987). The results showed that DLBS1033N could induce neurite growth in PC-12 cell line (Fig. 7). There was no neurite outgrowth detected on sample without treatments. Sample with $0.1 \mathrm{ng} \mathrm{mL} \mathrm{m}^{-1} \mathrm{NGF}$ experienced neurite outgrowth (Fig. 7B) and sample treated with DLBS1033N $50 \mu \mathrm{g} \mathrm{mL} \mathrm{m}^{-1}$ experienced higher neurite outgrowth (Fig. 7C).

\section{DLBS1033N Up-Regulated PI3K Related Genes}

In order to find the mechanism activated by DLBS1033N, several gene expression from PI3K and MAPK pathways were investigated. DLBS1033N action on growth and survival is likely done via NGF-PI3K pathway (Table 2). Several gene expressions on MAPK pathway was tend to be down-regulated. DLBS1033N at $50 \mu \mathrm{g} \mathrm{mL}^{-1}$ upregulated PI3K gene expressions for 2.43 fold compared to the control, then followed by the upregulation of the Akt gene expressions for 1.5 fold compared to the control. The BAD gene expressions were downregulated to 0.51 fold compared to the control. BCL-2 and BCL-xL were up-regulated by 2.12 and 1.34 fold, respectively, compared to the control.

\section{Discussion}

Proteins have diverse functions in living organisms, such as catalyzing biochemical reaction, transporting molecule and forming receptors and channels. With these diverse functions, proteins can be used for therapy. Therapeutic proteins have several advantages compared to small molecule drugs which include better specific actions and less adverse effects. Therapeutic proteins can also provide novel function or activity. Therapeutic proteins are mostly in the form of recombinant proteins. However, some therapeutic proteins can be obtained from their native sources (Leader et al., 2008; Carter,
2011; Dmitrov, 2012). DLBS1033N is a protein fraction obtained from a natural resource, which is earthworm Lumbricus rubellus. In this study, DLBS1033N functions on Schwann cells exhibited its potential to be a therapeutic protein.

Schwann cells are one of the important factors in peripheral nerve regeneration process. Schwann cells help the nerve regeneration with its proliferation and differentiation process (Bunge, 1993; 1994; Ide, 1996). In this study, DLBS1033N was found to induce Schwann cells growth and survival. The ischemic factor can induce nerve injury. Weinberg et al. (2001) showed that people with critical limb ischemia can develop peripheral neuropathy. In this study, the investigation was focused on the ischemic factor. Two conditions were conducted in this study, which consisted of free serum condition and free serum with the minimum $\mathrm{O}_{2}$ condition to mimick ischemic conditions. The observation showed that Schwann cells treated with DLBS1033N in free serum condition was resulted in higher cells population compared to the control, which was observed in 48 and $72 \mathrm{~h}$ of treatments. In free serum with minimum $\mathrm{O}_{2}$ condition, Schwann cells treated with DLBS1033N for $24 \mathrm{~h}$ also showed higher cells population compared to the control.

In two different conditions, it was observed that DLBS1033N increased Schwann cells growth and survival. These results are indicated by the better survival of the Schwann cells at ischemic conditions with DLBS1033N treatment. FACS analysis also showed that samples treated with DLBS1033N have higher detected $\mathrm{S}$ phase compared to the control at 24, 36 and $48 \mathrm{~h}$ of treatments. It indicated that DLBS1033N increased cell proliferation activity. Kobayashi et al. (2012) and Jonsson et al. (2013) revealed that Schwann cell proliferation is a crucial step in nerve regeneration after ischemic nerve injury. Therefore, DLBS1033N actions on Schwann cells growth and survival are likely to exert several advantages in nerve regeneration process after ischemic injury. 
The release of neurotrophins is also one of the Schwann cells activity on nerve regeneration process (Bunge, 1994). Neurotrophins are important regulators of neuronal survival, development, function and plasticity (Huang and Reichardt, 2001). Neurotrophins that have been characterized in mammals were NGF, BDNF, NT-3 and NT-4. Each neurotrophin has its own specific receptor (Hallbook, 1999). In this study, the effect of DLBS1033N on NGF and BDNF gene expressions were investigated. Other growth factors such as FGF and GDNF gene expressions were also observed. The experiments showed that DLBS1033N upregulated NGF gene expressions. The study was then continued at the protein level and found that NGF protein was also increased in a time-dependent manner. These two results indicated that growth and survival activities on Schwann cells were related to NGF expressions. Receptor inhibition assay was conducted to confirm the results. Neurotrophin NGF binds to TrkA receptors which can be inhibited by GW441756 (Jung et al., 2008; Jung and Kim, 2008; Takemoto et al., 2015). In inhibition study, the proliferation of DLBS1033N-treated Schwann cells were inhibited in a dose-dependent manner following GW441756 administrations. This result indicates that the growth and survival activities were induced by DLBS1033N which was also related to NGF expressions.

Based on growth-survival and NGF assays, it appeared that DLBS1033N was able to promote growthsurvival of Schwann cells with NGF induction activity. DLBS1033N showed the potential to be a therapeutic protein for nerve regenerations. Earthworm extract is usually used for its lumbrokinase activity. Some studies, however, have revealed that earthworm extract can be used in nerve regeneration treatments. Chang et al. (2011a; 2011b) reported that Dilong can promote Schwann cells proliferation and migration. Dilong is consisted of earthworm Pheretima aspergillum. The earthworm species is different from Lumbricus rubellus which was used to prepare DLBS1033N. According to study by Chang et al. (2011a), Dilong was found to promote Schwann cell proliferation via IGF activation. The result is different to the current study which demonstrated the activity ofDLBS1033N to promote Schwann cell proliferation via NGF induction. However, IGF expression was not further investigated in this study. Further studies may be needed to observe the effect of DLBS1033N on IGF expressions. Other study using earthworm Pheretima aspergillum was done by Chen et al. (2010). According to their study, Pheretima aspergillum water extract induced peripheral nerve regeneration in vitro and in vivo. Their in vitro study using PC12 cells revealed that Pheretima aspergillum water extract promoted neurite outgrowth in $\mathrm{PC} 12$ cells. In this study, DLBS1033N was also used in neurite outgrowth analysis. Experiment using PC12 cells line showed that the neurites outgrowth were detected in DLBS1033N-treated cells. This result indicates that DLBS1033N can promote neurites outgrowth on nerve cell models. In this study, it was indicated that DLBS1033N is likely not only work on Schwann cells but also on nerve cells model. Therefore, DLBS1033N is potential to be used as a therapeutic protein for peripheral nerve regenerations.

When NGF binds to TrkA receptor, it can activate several pathways such as PI3K and MAPK. Those two pathways are related to cells survival. Neurotrophins bind as dimers to p75 and Trk family members. Trk receptor dimerization leads to trans-autophosphorylation and activation of intracellular signaling cascades which increases PI3K and Akt activities. It also leads to the increased activity of MAPK (Huang and Reichardt, 2001; Yuan and Yankner, 2000; Chao, 2003).

In this study, several genes expressions related to PI3K and MAPK pathways were investigated. The result showed that PI3K pathway was more likely to be affected. Several genes that have been observed in PI3K pathway were PI3K, Akt, BAD, BCL-2 and BCL-xL. The investigation showed that DLBS1033N up-regulated PI3K gene expressions. Activation of PI3K is essential for the survival of many populations of neurons. Activation of PI3K will be followed by Akt activation. Several biological functions for cell survival were controlled and regulated by Akt (Datta et al., 1999). Akt gene expressions in this study was also up-regulated. The other PI3K pathway genes observed were BAD, BCL-2 and BCL-xL. BAD plays a role in promoting cell death, while BCL-2 and BCL-xL promote cell survival. $\mathrm{BAD}$ is one of the Akt substrates. It is a BCL-2 family member that promotes apoptosis by binding to BCL-xL, which in the absence of binding will further inhibit the proapoptotic activity of Bax (Datta et al., 1999; 1997). In this study, BAD gene expressions were downregulated. Therefore, chances for cells to experience apoptosis are less. Lesser chance for cells undergoing apoptosis is convinced with the upregulation of BCL-2 and BCL-xL gene expressions. BCL-2 and BCL-xL are BCL-2 family members that promote cell survival whereas other member such as Bax and BAD promote cell death. In the presence of survival factors, the activity of prosurvival BCL-2 family members prevails over the activity of prodeath BCL-2 family members (Datta et al., 1999).

Activation of Trk receptor also increases MAPK activity. These in turn influence transcriptional events, such as the induction of cyclic AMP-Response Element Binding (CREB) transcription factor. CREB affects the cell cycles, neurite outgrowth and synaptic plasticity (Huang and Reichardt, 2001). MAPK gene expressions was down-regulated, which further also caused the downregulation of CREB gene expressions. The other MAPK pathway related genes are C-FOS and C-MYC. 
MAPK is also known as ERK, one of the MAPK families. ERK is known to be an intracellular check point for cellular mitogenesis. ERK activation can induce immediate early gene C-FOS. The ERK can link G0/G1 mitogenic signals to the immediate early response. CMYC was also activated following the activation of ERK. $\mathrm{C}-\mathrm{MYC}$ is a DNA binding protein which is involved in transcriptional control of gene expression and has been known to be essential in cell proliferation (Zhang and Liu, 2002). In this study, C-FOS and C-MYC were downregulated. However, the Schwann cells were grew and survived. Therefore, there might be other pathways that lead the Schwann cells to grow. Further study of DLBS1033N on MAPK pathway might be needed.

\section{Conclusion}

In summary, DLBS1033N was found to promote the growth and survival of Schwann cells in free serum and free serum-minimum $\mathrm{O}_{2}$ conditions. DLBS1033N was also able to induce NGF expressions. These two activities play important roles in peripheral nerve regenerations. In addition to the effect of DLBS1033N in Schwann cells, DLBS1033N also exhibited an activity in inducing neurite outgrowth on nerve cell model PC12 cell lines. These activities on Schwann cells and PC12 cell lines support DLBS1033N as a potential therapeutic protein candidate for peripheral nerve regenerations.

\section{Acknowledgment}

This study was supported by Dexa Laboratories of Biomolecular Sciences, PT. Dexa Medica, Indonesia.

\section{Author's Contributions}

Agung Heru Karsono: was responsible for the design, execution of the experimentation and analytical evaluation of the data and contributed to the writing of manuscript.

Raymond R. Tjandrawinata: was responsible for the design, execution of analytical evaluation and contributed to the writing of manuscript.

Maggy T. Suhartono: was responsible for the execution of analytical evaluation and contributed to the writing of manuscript.

\section{Conflict of Interest}

The authors declare no conflict of interest.

\section{References}

Bunge, R.P., 1993. Expanding roles for the Schwann cell: Ensheathment, myelination, trophism and regeneration. Neurobiology, 3: 805-809.

DOI: 10.1016/0959-4388(93)90157-T
Bunge, R.P., 1994. The role of the Schwann cell in trophic support and regeneration. J. Neurol., 241: S19-S21. DOI: 10.1007/BF00939235

Carter, P.J., 2011. Introduction to current and future protein therapeutics: A protein engineering perspective. Experi. Cell Res., 311: 1261-1269. DOI: 10.1016/j.yexcr.2011.02.013

Chang, Y.M., W.H. Kuo, T.Y. Lai and Y.T. Shih et al., 2011a. RSC96 Schwann cell proliferation and survival induced by dilong through PI3K/Akt signaling mediated by IGF-I. Evid. Based Complement. Alternat. Med.

DOI: $10.1093 /$ ecam/nep216

Chang, Y.M., W.Y. Chi, T.Y. Lai, Y.S. Chen and F.J. Tsai et al., 2011b. Role in peripheral nerve regeneration. Evid. Based Complement. Alternat. Med. PMID: 21799677

Chang, Y.M., Y.T. Shih, Y.S. Chen, C.L. Liu and W.K. Fang et al., 2009. Schwann cell migration induced by earthworm extract via activation of PAs and MMP2/9 mediated through ERK1/2 and p38. Evidence-Based Complementary Alternative MediceneI. DOI: 10.1093/ecam/nep131

Chao, M.V., 2003. Neurotrophins and their receptors: A convergence point for many signalling pathways. Neuroscience, 4: 299-309. PMID: 12671646

Chen, C.T., J.G. Lin, T.W. Lu, F.J. Tsai and C.Y. Huang et al., 2010. Earthworm extracts facilitate PC12 cell differentiation and promote axonal sprouting in peripheral nerve injury. Am. J. Chinese Med., 38: 547-560. PMID: 20503471

Chen, Z.L., W.M. Yu and S. Strickland, 2007. Peripheral regeneration. Ann. Rev. Neurosci., 30: 209-233. PMID: 17341159

Cho, I.H., E.S. Choi, H.G. Lim and H.H. Lee, 2004. Purification and characterization of six fibrinolytic serine-proteases from earthworm Lumbricus rubellus. J. Biochem. Molecular Biol., 37: 199-205. PMID: 15469696

Datta, S.R., A. Brunet and M.E. Greenberg, 1999. Cellular survival: A play in three Akts. Genes Develop., 13: 2905-2927. PMID: 10579998

Datta, S.R., H. Dudek, X. Tao, S. Masters and H. Fu et al., 1997. Akt phosphorylation of BAD couples survival signals to the cell-intrinsic death machinery. Cell, 91: 231-241. PMID: 9346240

Dmitrov, D.S., 2012. Therapeutic proteins. Methods Mol. Biol., 899: 1-26. DOI: $10.1007 / 978-1-61779-921-11$

Greene, L.A., J.M. Aletta, A. Rukenstein and S.H. Green, 1987. PC12 pheochromocytoma cells: Culture, nerve growth factor treatment and experimental exploitation. Methods Enzymol., 147: 207-216. PMID: 3670084

Hallbook, F., 1999. Evolution of the vertebrate neurotrophin and Trk receptor gene families. Curr. Opin. Neurobiol., 9: 616-621. PMID: 10508739 
Huang, E.J. and L.F. Reichardt, 2001. Neurotrophins: roles in neuronal development and function. Ann. Rev. Neurosci., 24: 677-736. PMID: 11520916

Ide, C., 1996. Peripheral nerve regeneration. Neurosci. Res., 25: 101-121. PMID: 8829147

Jonsson, S., R. Wiberg, A.M. McGrath, L.N. Novikov and M. Wiberg et al., 2013. Effect of delayed peripheral nerve repair on nerve regeneration, Schwann cell function and target muscle recovery. PLoS One, 8: e56484-e56484. DOI: 10.1371/journal.pone.0056484

Jung, E.J. and D.R. Kim, 2008. Apoptotic cell death in TrkA-overexpressing cells: Kinetic regulation of ERK phosphorylation and caspase-7 activation. Mol. Cells, 26: 12-17. PMID: 18511888

Jung, E.J., C.W. Kim and D.R. Kim, 2008. Cytosolic accumulation of $\gamma \mathrm{H} 2 \mathrm{AX}$ is associated with tropomyosin-related kinase A-induced cell death in U2OS cells. Exp. Mol. Med., 40: 276-285. DOI: $10.3858 / \mathrm{emm} .2008 .40 .3 .276$

Kobayashi, M., S. Ishibashi, H. Tomimitsu, T. Yokota and H. Mizusawa, 2012. Proliferating immature Schwann cells contribute to nerve regeneration after ischemic peripheral nerve injury. J. Neuropathol. Exp. Neurol., 71: 511-519. PMID: 22588387

Leader, B., Q.J. Baca and D.E. Golan, 2008. Protein therapeutics: A summary and pharmacological classification. Nature Rev. Drug Discovery, 7: 21-39. PMID: 18097458

Lewin, G.R. and Y.A. Barde, 1996. Physiology of the neurotrophins. Ann. Rev. Neurosci., 19: 289-317.

Mihara, H., H. Sumi, T. Yoneta, H. Mizumoto and R. Ikeda et al., 1991. A novel fibrinolytic enzyme extracted from the earthworm, Lumbricus rubellus. Japanese J. Physiol., 41: 461-472. PMID: 1960890

Mihara, H., T. Yoneta, H. Sumi, M. Soeda and M. Maruyama, 1989. A possibility of erathworm powder as therapeutic agent for thrombosis. Thromb. Haemosta, 62: 545-549.
Smit, M., J. Leng and R.L. Klemke, 2003. Assay for neurite outgrowth quantification. Biotechniques, 35: 254-256. PMID: 12951763

Takemoto, T., Y. Ishihara, A. Ishida and T. Yamazaki, 2015. Neuroprotection elicited by nerve growth factor and brain-derived neurotrophic factor released from astrocytes in response to methylmercury. Environ. Toxicol. Pharmacol., 40: 199-205. DOI: $10.1016 /$ j.etap.2015.06.010

Trisina, J., F. Sunardi, M.T. Suhartono and R.R. Tjandrawinata, 2011. DLBS1033, a protein extract from Lumbricus rubellus, possesses antithrombotic and thrombolytic activities. J. Biomed. Biotechnol. DOI: $10.1155 / 2011 / 519652$

Verma, M.K. and K.K. Pulicherla, 2011. LumbrokinaseA potent and stable fibrin-specific plasminogen activator. Int. J. Bio-Sci. Bio-Technol., 3: 57-70.

Weinberg, D.H., D. Simovic, J. Isner and A.H. Ropper, 2001. Chronic ischemic monomelic neuropathy from critical limb ischemia. Neurology, 57: 1008-1012. PMID: 11571325

Yang, C., J. Zhao, Y. Cheng, X. Li and J. Rong, 2014. Bioactivity-guided fractionation identifies amygdalin as a potent neurotrophic agent from herbal medicine Semen persicae extract. BioMed Res. Int. PMID: 25050339

Yuan, J. and B.A. Yankner, 2000. Apoptosis in the nervous system. Nature, 407: 802-809. PMID: 11048732

Zhang, N., H Yan and X. Wen, 2005. Tissue-engineering approaches for axonal guidance. Brain Res. Rev., 49: 48-64. PMID: 15960986

Zhang, W. and H.T. Liu, 2002. MAPK signal pathways in the regulation of cell proliferation in mammalian cells. Cell Res., 12: 9-18. DOI: $10.1038 /$ sj.cr.7290105 